\title{
Thermo-erosion gullies boost the transition from wet to mesic tundra vegetation
}

\author{
Naïm Perreault ${ }^{1,2}$, Esther Lévesque ${ }^{1,2}$, Daniel Fortier ${ }^{2,3}$, and Laurent J. Lamarque Lam $^{1,2}$ \\ ${ }^{1}$ Département des sciences de l'environnement, Université du Québec à Trois-Rivières, Trois-Rivières, \\ QC, G9A 5H7, Canada \\ ${ }^{2}$ Centre d'études nordiques, Université Laval, Québec, QC, G1V 0A6, Canada \\ ${ }^{3}$ Département de géographie, Université de Montréal, Montréal, QC, H2V 2B8, Canada
}

Correspondence to: Esther Lévesque (esther.levesque@uqtr.ca) and Laurent J. Lamarque (1lamarqueab@gmail.com)

Received: 29 June 2015 - Published in Biogeosciences Discuss.: 5 August 2015

Revised: 24 January 2016 - Accepted: 1 February 2016 - Published: 1 March 2016

\begin{abstract}
Continuous permafrost zones with well-developed polygonal ice-wedge networks are particularly vulnerable to climate change. Thermo-mechanical erosion can initiate the development of gullies that lead to substantial drainage of adjacent wet habitats. How vegetation responds to this particular disturbance is currently unknown but has the potential to significantly disrupt function and structure of Arctic ecosystems. Focusing on three major gullies of Bylot Island, Nunavut, we estimated the impacts of thermoerosion processes on plant community changes. We explored over 2 years the influence of environmental factors on plant species richness, abundance and biomass in 62 low-centered wet polygons, 87 low-centered disturbed polygons and 48 mesic environment sites. Gullying decreased soil moisture by $40 \%$ and thaw-front depth by $10 \mathrm{~cm}$ in the center of breached polygons within less than 5 years after the inception of ice wedge degradation, entailing a gradual yet marked vegetation shift from wet to mesic plant communities within 5 to 10 years. This transition was accompanied by a five times decrease in graminoid above-ground biomass. Soil moisture and thaw-front depth changed almost immediately following gullying initiation as they were of similar magnitude between older ( $>5$ years) and recently ( $<5$ years) disturbed polygons. In contrast, there was a lag-time in vegetation response to the altered physical environment with plant species richness and biomass differing between the two types of disturbed polygons. To date (10 years after disturbance), the stable state of the mesic environment cover has not been fully reached yet. Our results illustrate that wetlands are highly vulnerable to thermo-erosion processes, which drive landscape transfor-
\end{abstract}

mation on a relative short period of time for High Arctic perennial plant communities (5 to 10 years). Such succession towards mesic plant communities can have substantial consequences on the food availability for herbivores and carbon emissions of Arctic ecosystems.

\section{Introduction}

Warming in the Arctic is occurring twice as fast as the global average (USGCRP, 2009; New et al., 2011; NOAA, 2014). Perennially frozen ground (permafrost) has consequently warmed by $2{ }^{\circ} \mathrm{C}$ over the last 20 to 30 years (Christiansen et al., 2010; Romanovsky et al., 2010), and there is now evidence of a decrease in both permafrost area extent across the Northern Hemisphere and permafrost thickness at the local scale (Beilman and Robinson, 2003; Payette et al., 2004; Smith, 2011).

Permafrost is tightly associated with biophysical components such as air temperatures, soil conditions, surface water, groundwater, snow cover and vegetation (Jorgenson et al., 2010; Sjöberg, 2015). Permafrost impedes water to drain to deeper soil layers and maintains a perched water table and saturated soils which favors the existence of wetlands (Woo, 2012; Natali et al., 2015). Permafrost degradation that would increase subsurface drainage and reduce the extent of lakes and wetlands at high latitudes (Avis et al., 2011; Jorgenson et al., 2013; Beck et al., 2015) would thus have major consequences on ecosystem structure and function (Collins et al., 2013; Jorgenson et al., 2013). It would also strongly influ- 
ence variations of active layer depths (Wright et al., 2009; Shiklomanov et al., 2010; Gangodagamage et al., 2014), as illustrated by long-term monitoring sites throughout the circumpolar North (Tarnocai et al., 2004; Nelson et al., 2008; Smith et al., 2009; Shiklomanov et al., 2010).

Several forms of ground and massive ice can be found within permafrost (Rowland et al., 2010), especially ice wedges in regions where winter temperatures enable thermal contraction cracking (Fortier and Allard, 2005; Kokelj et al., 2014; M. T. Jorgenson et al., 2015; Sarrazin and Allard, 2015). Continuous permafrost zones with well-developed polygonal ice-wedge networks are particularly vulnerable to climate change because ice wedges are usually found near the top of permafrost (Smith et al., 2005; Jorgenson et al., 2006; Woo et al., 2008; Vonk et al., 2013). In these regions, thawing permafrost can result in ground ice erosion and displacement of sediments, carbon and nutrients by drainage (Rowland et al., 2010; Godin et al., 2014; Harms et al., 2014). This thermo-erosion process has especially been observed across North-America (Grosse et al., 2011), in Siberia (Günther et al., 2013) and in the Antarctic Dry Valleys (Levy et al., 2008). On Bylot Island, Nunavut, thermo-mechanical erosion by water has initiated permafrost tunneling and the development of gully networks in aeolian, organic and colluvial depositional environments of nearly $158000 \mathrm{~m}^{2}$ (Fortier et al., 2007; Godin and Fortier, 2012a; Godin et al., 2014; Veillette et al., 2015). A fine-scale spatio-temporal monitoring of the six largest gullies showed that their development rates ranged from 14 to $25 \mathrm{~m} \mathrm{yr}^{-1}$ going up to $80 \mathrm{~m} \mathrm{yr}^{-1}$ during their inception (Godin and Fortier, 2012b), leading to substantial changes in the drainage network and increasing eroded area throughout the valley (Godin et al., 2014). To date, the contribution of thermal-erosion and lateral erosion processes in permafrost feedbacks to climate has yet to be documented.

Many observational and experimental studies have highlighted shifts in tundra plant community structure and plant species productivity in response to warming temperatures (Jonsdottir et al., 2005; Hudson and Henry, 2010; Epstein et al., 2013; Naito and Cairns, 2015). In contrast, little is known about how thermo-erosion gullying affects plant community structure and plant species abundance. Yet, this information is urgently needed as vegetation plays an important role in structuring Arctic ecosystems and regulating permafrost response to climate change (Jorgenson et al., 2010; Gauthier et al., 2011; Legagneux et al., 2012). Wetlands serve as preferred grounds for Arctic herbivores such as snow geese (Gauthier et al., 1996; Massé et al., 2001; Doiron et al., 2014). They are also expected to produce more methane compared to shrub-dominated areas (Olefeldt et al., 2013; Nauta et al., 2015; Treat et al., 2015).

The present study aimed at examining plant community patterns following thermo-erosion gullying processes. Bylot Island, where geomorphological and ecological processes in response to climate change have been monitored for over
2 decades (Allard, 1996; Fortier and Allard, 2004; Gauthier et al., 2013; Godin et al., 2014), offered a unique opportunity to specifically assess the response of wetlands to gullying. The following questions were addressed: (1) to what extent thermo-erosion gullying modifies environmental conditions of low-centered wetland polygons? (2) How do plant communities cope with these geomorphological changes, i.e. do we observe shifts in plant diversity, abundance and productivity?

\section{Methods}

\subsection{Study area}

This study took place in the Qarlikturvik valley of Bylot Island, Nunavut, Canada $\left(73^{\circ} 09^{\prime} \mathrm{N}, 79^{\circ} 57^{\prime} \mathrm{W}\right.$; Fig. 1a). Bound to the North and South by plateaus < 500 ma.s.l., it connects C-79 and C-93 glaciers to the Navy Board Inlet sea via a proglacial river. The sampling sites were specifically located on the valley floor (ca. $65 \mathrm{~km}^{2}$ ), which is characterized by a low-centered polygon landscape that has resulted from ice wedges development and sediment accumulation during the late Holocene (Ellis and Rochefort, 2004; Fortier and Allard, 2004; Fortier et al., 2006; Ellis et al., 2008). Two baseline vegetation types can be recognized. Wetlands, often associated with intact low-centered polygons, represent ca $23 \%$ of the valley area (Hughes et al., 1994) and are dominated by sedges (Carex aquatilis, Eriophorum angustifolium, Eriophorum scheuchzeri), grasses (Dupontia fisheri, Pleuropogon sabinei; Gauthier et al., 1995) and fen mosses (Drepanocladus spp.; Ellis et al., 2008; Pouliot et al., 2009). Mesic environments, such as low-centered polygon rims, gently sloping terrain and hummocky tundra, support a more diverse group of species including Salix spp., Vaccinium uliginosum, Arctagrostis latifolia, Poa arctica and Luzula confusa with Aulacomnium spp. as dominant moss species (Zoltai et al., 1983). As a result, the valley houses many herbivores such as snow geese (in summer) and brown and collared lemmings (Gauthier et al., 1995; Gruyer et al., 2008), thus representing a critical environment for tundra food web (Gauthier et al., 2011; Legagneux et al., 2012).

\subsection{Field sites}

Our work was specifically conducted around three gullies that were selected among the 36 identified in the valley (Godin and Fortier, 2012b). These gully networks have originated from snowmelt water infiltration into cavities of the frozen active layer and the subsequent formation of underground tunnels that have ended up collapsing (Fortier et al., 2007; Godin and Fortier, 2010). The gullies R08p and R06, respectively 835 and $717 \mathrm{~m}$ long, are characterized by ongoing thermo-erosion processes (Fortier et al., 2007; Godin and Fortier, 2012b) whilst the gully RN08, $180 \mathrm{~m}$ long, has not been actively eroding in recent years. A total of 197 

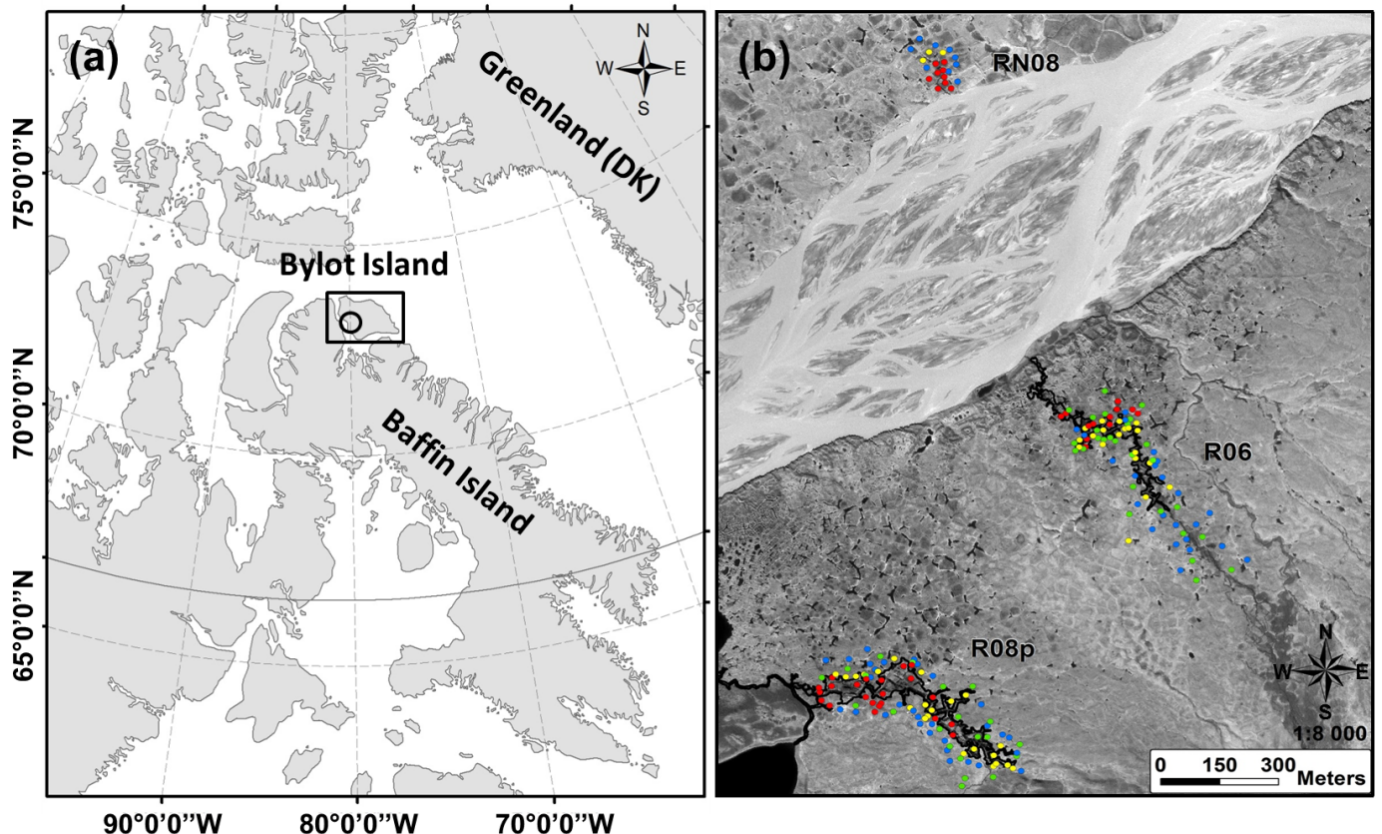

Figure 1. Location of the study area. (a) The Qarlikturvik valley (black circle), Bylot Island (black rectangle), Nunavut. (b) The 197 sampling sites located along the three selected gullies (wet polygons $(n=62)$ : blue circles; <5-year disturbed polygons $(n=44)$ : yellow circles; > 5year disturbed polygons $(n=43)$ : red circles; mesic environments $(n=48)$ : green circles $)$.

sampling sites were randomly selected around the three gullies (Table 1; Fig. 1b) and classified into one of four categories (referred hereafter as habitats) that represented the two baseline vegetation types (wet and mesic) as well as increasing levels of disturbance related to thermo-erosion processes. The disturbed habitats were sorted via a visual assessment of the low-centered polygon rim integrity coupled with a recent close monitoring of drainage system development along the gullies (Fortier et al., 2007; Godin and Fortier, 2012a, b). The habitats were defined as follows: (i) intact low-centered wet polygons $(n=62)$ that were not affected by gullying. Their elevated rims enclose a central depression that retains snow cover during winter and is flooded by snowmelt water during spring (Woo and Young, 2006; Minke et al., 2007). These polygons are hydrologically independent, with their water content representing the balance between precipitation inputs (snow and rain) and evapotranspiration outputs (Fortier et al., 2006); (ii) less than 5-year (recently) disturbed polygons $(n=44)$, located along the most recent sections of the gullies, with partially degraded rims, incomplete drainage and heterogeneous water content; (iii) more than 5-year (older) disturbed polygons ( $n=43$ ), with heavily breached rims adjacent to the gully channels and substantial or complete drainage; (iv) mesic environments $(n=48)$, with distinct heterogeneous mesic vegetation. They are found on the rim of polygons and in adjacent areas and are generally not induced by thermo-erosion gullying but rather dependent on local sedimentary and hydrological dynamics.

\subsection{Environmental condition monitoring}

Daily precipitation was recorded with a manual rain gauge throughout summer 2010 at the base camp, located $700 \mathrm{~m}$ west of the gully R08p (Gauthier et al., 2010). Soil (top $10 \mathrm{~cm}$ ) moisture was recorded at the center of each sampling site using $\mathrm{ECH}_{2} \mathrm{O}$ EC-5 moisture sensors (accuracy of $\pm 3 \%$ VWC, resolution of $\pm 0.1 \%$ VWC) connected to Em5b data loggers (Decagon Devices). Measurements were carried out in 2010, both 5 July (early season) and 30 July (late season) along the gullies R08p and R06, and only 30 July along the gully RN08. Thaw-front depth was recorded at the center of each sampling site using a graduated steel rod driven into the thawed active layer. The data collection spanned 2 years with measurements in July 2009 and 2010 in the polygons of the gullies R08p and R06 and in July 2010 in those situated along the gully RN08. One measure was taken in each of the wet and disturbed sampled polygons whereas three random measurements were conducted in each mesic environment site because of the heterogeneity of this type of habitat. In this case, a mean per site was calculated prior to analyses. 
Table 1. Distribution of the sampling sites per habitat type and per gully.

\begin{tabular}{lrrrrr}
\hline Gullies & \multicolumn{5}{c}{ Habitats } \\
\cline { 2 - 6 } & $\begin{array}{r}\text { Wet } \\
\text { polygons }\end{array}$ & $\begin{array}{r}\text { <-year } \\
\text { disturbed } \\
\text { polygons }\end{array}$ & $\begin{array}{r}>\text { 5-year } \\
\text { disturbed } \\
\text { polygons }\end{array}$ & $\begin{array}{r}\text { Mesic } \\
\text { environments }\end{array}$ & Total \\
& & 22 & 22 & 21 & 95 \\
R08p & 30 & 19 & 12 & 27 & 81 \\
R06 & 23 & 3 & 9 & 0 & 21 \\
RN08 & 9 & 44 & 43 & 48 & 197 \\
Total & 62 & 4 & & & \\
\hline
\end{tabular}

\subsection{Plant community characterization}

Species richness and abundance were determined at each site in July 2009 or 2010 using three randomly placed $70 \mathrm{~cm} \times 70 \mathrm{~cm}$ quadrats that were vertically photographed at ca $1.3 \mathrm{~m}$ from the ground (see detailed protocols in Chen et al., 2010 and the IPY CiCAT, 2012; Fig. 2). Abundances of vascular plants, lichens, mosses, Nostoc spp., fungi, cryptogamic crust, bare ground, litter, vascular plant standing dead, standing water, signs of grubbing and goose feces were evaluated as cover percentages using photography analyses (Perreault, 2012). Daubenmire cover abundance classes (Daubenmire, 1959) were used on each quadrat picture overlain by a $7 \mathrm{~cm}$ grid to evaluate species cover as the projection on the ground of all species above-ground parts.

Five sampling sites per habitat were also randomly selected along the gullies R08p and R06 to measure aboveground biomass of graminoid species. At each site, an exclosure of $1 \mathrm{~m} \times 1 \mathrm{~m}$ was made of chicken wire $30 \mathrm{~cm}$ high and supported by wooden stakes at each corner (see Gauthier et al., 1995). Exclosures were set up in early July 2012 to avoid any significant grazing by geese. Above-ground biomass was harvested inside the exclosures near peak production in early August 2012 using random grids of $25 \mathrm{~cm} \times 25 \mathrm{~cm}$ for wet and recently disturbed polygons and of $50 \mathrm{~cm} \times 20 \mathrm{~cm}$ for older disturbed polygons and mesic environments. Two different grid sizes were used because of the difference in structure of the vegetation (herbaceous vs. shrubs) associated with the habitat heterogeneity (Legagneux et al., 2012). All graminoids present in the random grids were cut to a standard height, i.e. at an average of $1 \mathrm{~cm}$ below the moss surface (Gauthier et al., 1995; Doiron et al., 2014), and live biomass was sorted as follows: Carex aquatilis, Eriophorum angustifolium and Eriophorum scheuchzeri (Cyperaceae); Luzula arctica and Luzula confusa (Juncaceae); Anthoxanthum arcticum, Arctagrostis latifolia, Dupontia fisheri and Festuca brachyphylla (Poaceae). Biomass was then oven-dried at $65^{\circ} \mathrm{C}$ until constant dry weight and further weighed to $\pm 0.0001 \mathrm{~g}$ using an electronic weighing scale.

\subsection{Statistical analyses}

Differences in soil moisture, thaw-front depth and graminoid above-ground biomass among habitats were tested with a generalized linear mixed model (procedure MIXED, REML method in SAS, version 9.4, SAS Institute, Cary, NC, USA). Soil moisture, thaw-front depth as well as date or year of measurements and the interaction terms were treated as fixed factors and gully as a random factor. Type III sums of squares were used for the calculation of fixed effect $F$ statistics while random effects were assessed using a log likelihood ratio test from the full and reduced models (Littell et al., 2006). Post hoc contrasts were performed to ascertain specific differences between habitats at alpha $<0.05$ using the LSMEANS statement and Bonferroni adjustment. Canonical correspondence analyses (CCA) were conducted to test unimodal relationships between habitats and environmental variables (ter Braak, 1986; Zuur et al., 2007) using the "vegan" package (Oksanen et al., 2015) in R 3.1.3 (R development core team, 2015). Two matrices were elaborated: one of 197 sites $\times 65$ taxa using their mean cover per site, and another of 197 sites $\times 8$ environmental characteristics comprising the following continuous variables: soil moisture, thaw front depth and cover estimates of litter, bare ground, grubbing, vascular plant standing dead, standing water and goose feces. Soil moisture measurements obtained on 30 July 2010 were used in the analyses.

\section{Results}

\subsection{Environmental conditions}

In 2009, above-average spring temperatures led to a rapid snowmelt (16 June) while summer was one of the driest on record (Gauthier et al., 2009). In 2010, despite a relatively warm spring $\left(0.26^{\circ} \mathrm{C}\right.$ above normal), the high snow pack at the end of the winter $(41.6 \mathrm{~cm}$ on 31 May) delayed the snowmelt in the lowlands to 28 June, which was a week later than normal. Summer was characterized by warm and sunny conditions as well as below-average precipitations (cumulative rain of $84 \mathrm{~mm}$ vs. long-time average of $92 \mathrm{~mm}$; Gauthier et al., 2010). However, the $36 \mathrm{~mm}$ received in only 5 days 


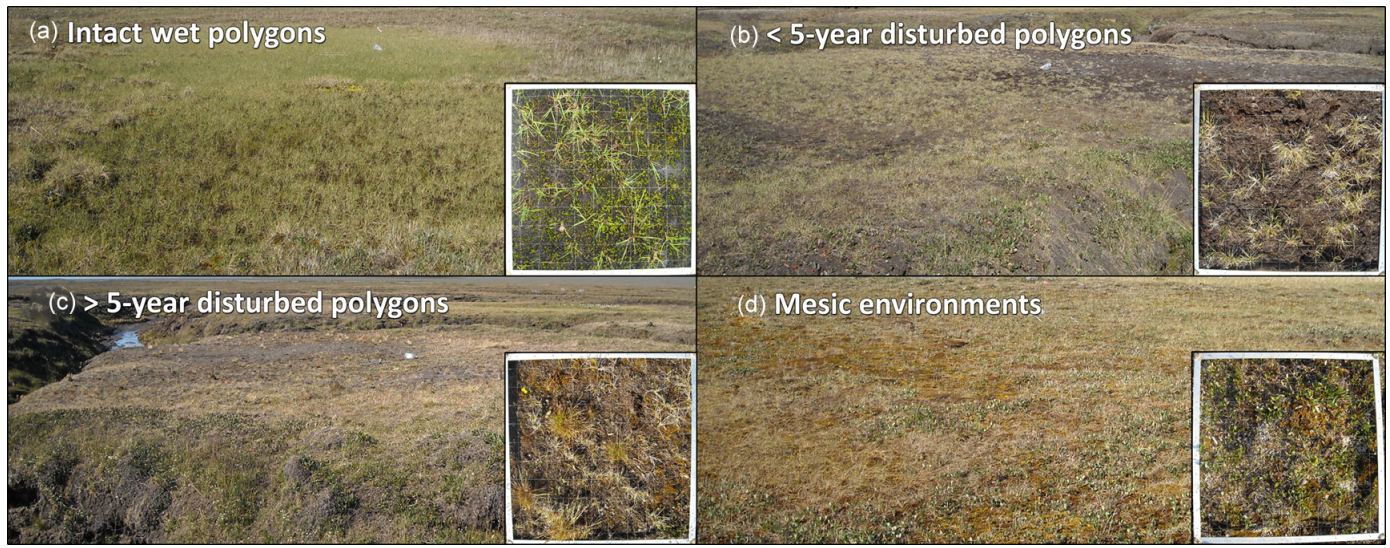

Figure 2. The four habitat types studied in the Qarlikturvik valley, Bylot Island, Nunavut. The close view at the bottom right of each picture represents the $70 \mathrm{~cm} \times 70 \mathrm{~cm}$ quadrats that were used to determine species richness and abundance in each sampling site.

in mid-July 2010 significantly increased soil moisture between the two monitoring dates in all habitats (significant date effect: $\mathrm{d} f=1, F=88.99, P<.001$; Fig. 3) . There was a significant difference overall in soil moisture among habitats $(\mathrm{d} f=3, F=79.86, P<0.001)$, which was associated with differences between wet polygons and the other habitats (5 July: $\mathrm{d} f=3, F=33.41, P<0.001,30$ July: $\mathrm{d} f=3, F=47.36, P<.001$; Fig. 3, Appendix Table A1). Throughout the summer, soil moisture was approximately $40 \%$ higher in wet polygons compared to disturbed polygons and mesic environments. We also found a significant difference in thaw-front depth between wet polygons and the other habitats (2009: $\mathrm{d} f=3, F=21.30, P<0.001,2010$ : $\mathrm{d} f=3, F=33.86, P<0.001$; Fig. 4 , Table A1). Thaw-front depth of wet polygons was approximately $10 \mathrm{~cm}$ deeper than in disturbed polygons and mesic environments for both years of monitoring (35-36 vs. $25-27 \mathrm{~cm}$ ). The two types of disturbed polygons thus showed similar soil moisture and thawfront depth despite their differing time since disturbance inception. There was no significant effect of gully location $(\mathrm{d} f=2, \mathrm{LLR}=1.6, P=0.21$ for soil moisture, $\mathrm{d} f=2$, $\mathrm{LLR}=0.0, P=1.0$ for thaw-front depth).

\subsection{Plant community characterization}

A total of 18 vascular plant families encompassing 59 species were sampled throughout the study (Table A2). The greatest species richness was found in polygons that were disturbed for at least 5 years and where both hydrophilic and mesic species were present (Table 2). The transition from wet polygons to mesic environments was accompanied by significant changes in vascular plant community composition, especially with the decline in Cyperaceae and Poaceae cover and the emergence of Salicaceae species (Table 2). Carex aquatilis and Dupontia fisheri were respectively present in 100 and $93 \%$ of the wet polygons sampled where they accounted for 52 and $26 \%$ of the total vascular plant cover.

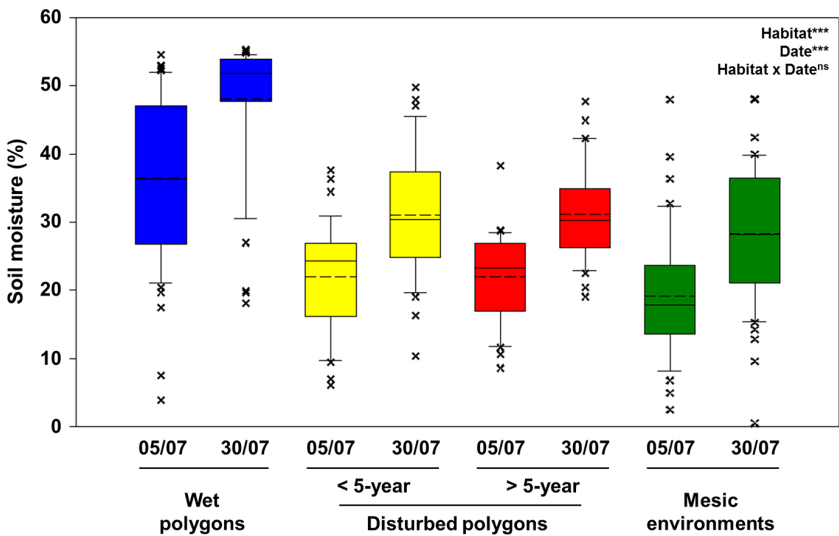

Figure 3. Soil moisture monitored early and late July 2010 in the four habitat types studied in the Qarlikturvik valley, Bylot Island, Nunavut. The 10th percentile, lower quartile, median (solid line), mean (dashed line), upper quartile and 90th percentile are shown. See Table A1 for sample sizes and post-hoc contrasts. ${ }^{* * *}$ $P<0.001$, ns: statistically non-significant effect.

They were found in only 47 and $16 \%$ of mesic environments accounting for 9 and $0.45 \%$ of the total vascular plant cover. In contrast, Salix arctica and Arctagrostis latifolia, which were found in approximately half of the wet polygons accounting for $3 \%$ of the total vascular plant cover, were present in $98 \%$ of the mesic environments where they respectively accounted for 50 and $14 \%$ of the total vascular plant cover. Differences among habitats were also noted in non-vascular taxa. Abundance of lichens such as Cladonia spp., Stereocaulon spp. and Peltigera spp. increased in polygons disturbed for at least 5 years and mesic environments (Table 2). Mosses were mostly found living in wet polygons and mesic environments and dried (i.e. dead) in disturbed polygons (Table 2), while a significant species turnover was observed between habitats with wetland-dominant 


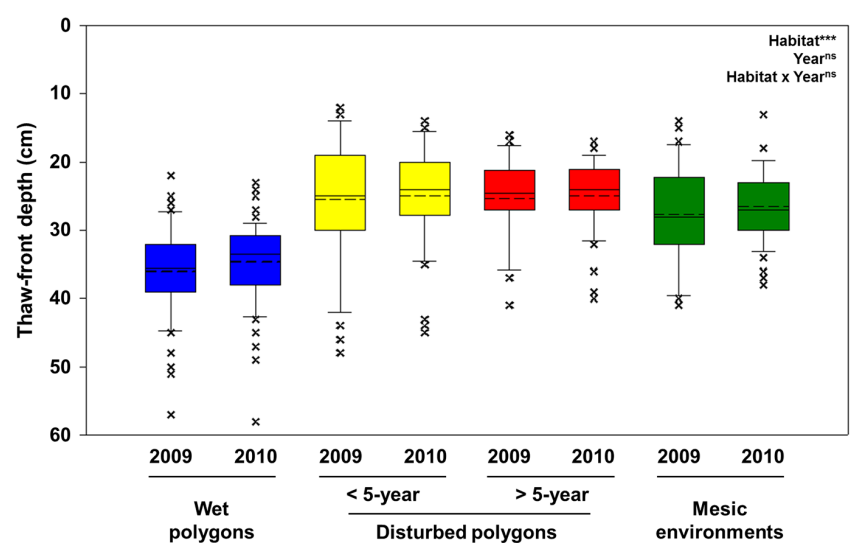

Figure 4. Thaw-front depth monitored in July 2009 and 2010 in the four habitat types studied in the Qarlikturvik valley, Bylot Island, Nunavut. The 10th percentile, lower quartile, median (solid line), mean (dashed line), upper quartile and 90th percentile are shown. See Table A1 for sample sizes and post-hoc contrasts. *** $P<0.001$, ns: statistically non-significant effect.

Drepanocladus species replaced by Aulacomnium species in mesic environments.

Moreover, we observed vegetation changes through the decline of graminoid above-ground biomass which varied significantly among habitats $(\mathrm{d} f=3, F=11.59, P<0.001$; Fig. 5a; Table A1). Graminoid biomass was nearly five times greater in wet than in mesic environments $(29.2 \mathrm{vs}$. $5.9 \mathrm{~g} \mathrm{~m}^{-2}$ ) and decreased twofold between $<5$-year disturbed and $>5$-year disturbed polygons ( 22.3 vs. $9.3 \mathrm{~g} \mathrm{~m}^{-2}$; Figs. 2 and 5a). Differences were mainly driven by the decline of hydrophilic species, i.e. Carex aquatilis, Eriophorum scheuchzeri, Anthoxanthum arcticum and Dupontia fisheri, between wet and mesic habitats $(28.8,19.7,3.6$ and $2.5 \mathrm{~g} \mathrm{~m}^{-2}$ in wet, < 5-year disturbed, > 5-year disturbed and mesic polygons, respectively; Fig. 5b). Above-ground biomass of Luzula spp., Arctagrostis latifolia and Festuca brachyphylla was contrastingly nine times greater in mesic than in wet habitats $\left(3.30\right.$ vs. $\left.0.35 \mathrm{~g} \mathrm{~m}^{-2}\right)$ and twenty-four times greater in $>5$-year disturbed than in $<5$-year disturbed polygons (5.61 vs. $0.23 \mathrm{~g} \mathrm{~m}^{-2}$ ).

\subsection{Relationships between plant communities and environmental variables}

The first two axes of the canonical correspondence analysis retained $14 \%$ of the vegetation data variance and $80 \%$ of the vegetation-environment relationship variance (Table 3 ). Five of the eight environmental variables tested were significant within the canonical model ( $P<0.05,999$ permutations), but only three - litter cover, thaw-front depth and soil moisture showed high correlations with the canonical axes (Table 4). Thaw-front depth and soil moisture were strongly related to the first axis, while litter cover was mainly associated with the second axis (Table 4). Altogether, these variables dis-

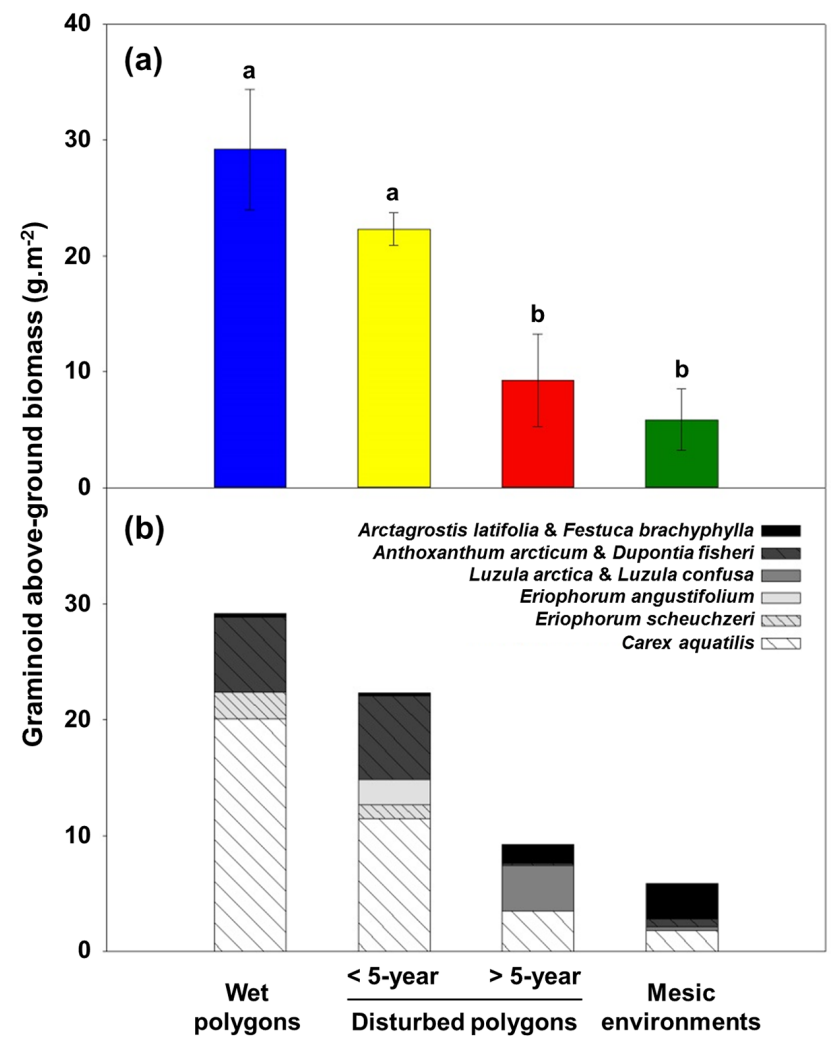

Figure 5. Above-ground biomass of graminoids growing in the four habitat types studied in the Qarlikturvik valley, Bylot Island, Nunavut. (a) Mean total biomass ( \pm SE), and (b) mean biomass per species. In panel (b), dashes represent hydrophilic species. $n=5$ per habitat. Species aforementioned belong to the following families: Cyperaceae (Carex aquatilis, Eriophorum angustifolium and Eriophorum scheuchzeri), Juncaceae (Luzula arctica and Luzula confusa), and Poaceae (Anthoxanthum arcticum, Arctagrostis latifolia, Dupontia fisheri and Festuca brachyphylla).

criminated well the four studied habitats of the Qarlikturvik valley. Wet polygons were mainly related to high soil moisture and substantial thaw-front depth whilst mesic environments were associated with greater litter cover (Fig. 6). The gradual vegetation transition was also observed from $<5$ year to $>5$-year disturbed polygons following the soil moisture shift in these habitats (Fig. 6).

\section{Discussion}

Sustainability of wetlands at high latitudes essentially relies on perennial frozen ground that prevents drainage and allows wet soil conditions (Woo and Young, 2006; Ellis et al., 2008). However, snowmelt water run-off through ice-wedge polygon landscapes can initiate thermal erosion of the permafrost and the development of gullies (Fortier et al., 2007; Godin and Fortier, 2014). We showed here that permafrost gullying significantly altered wetlands by changing the orig- 
Table 2. Species richness, family total cover and species mean cover of vascular taxa as well as mean cover of non-vascular taxa in each of the four habitat types studied in the Qarlikturvik valley, Bylot Island, Nunavut. Mean species richness is given for sampled areas of $49 \mathrm{dm}^{2}(70 \times 70 \mathrm{~cm}$ quadrats $)$. Numbers in brackets denote the number of species inventoried in each family. $\ll=$ cover $<0.01 \%$; $<=$ cover $<0.1 \%$. Species names were retrieved (2011) from the Integrated Taxonomic Information System (ITIS) (http://www.itis.gov).

\begin{tabular}{|c|c|c|c|c|}
\hline & \multirow{2}{*}{$\begin{array}{r}\text { Wet } \\
\text { polygons } \\
(n=62)\end{array}$} & \multicolumn{2}{|c|}{ Disturbed polygons } & \multirow{2}{*}{$\begin{array}{r}\text { Mesic } \\
\text { environments } \\
(n=48)\end{array}$} \\
\hline & & $\begin{array}{l}<5 \text { years } \\
(n=44)\end{array}$ & $\begin{array}{l}>5 \text { years } \\
(n=43)\end{array}$ & \\
\hline \multicolumn{5}{|l|}{ Vascular taxa } \\
\hline Total plant species richness & 36 & 37 & 54 & 47 \\
\hline Mean plant species richness & 8 & 11 & 17 & 15 \\
\hline \multicolumn{5}{|l|}{ Plant species cover $(\%)$} \\
\hline Asteraceae (3) & $\ll$ & $<$ & $<$ & $\ll$ \\
\hline Brassicaceae (8) & $<$ & $<$ & 0.3 & $<$ \\
\hline Caryophyllaceae (5) & $\ll$ & 0.1 & 1.0 & 0.2 \\
\hline Cyperaceae (4) & 17.4 & 18.5 & 7.0 & 1.9 \\
\hline Carex aquatilis & 14.7 & 17.8 & 6.4 & 1.9 \\
\hline Carex marina & 0 & $\ll$ & 0 & 0 \\
\hline Eriophorum angustifolium & 0.5 & 0.4 & 0.5 & 0 \\
\hline Eriophorum scheuchzeri & 2.1 & 0.4 & $\ll$ & $<$ \\
\hline Equisetaceae (1) & $<$ & $<$ & $<$ & $<$ \\
\hline Ericaceae (1) & 0 & 0 & $\ll$ & $<$ \\
\hline Fabaceae (2) & $\ll$ & $\ll$ & 0.2 & 0.1 \\
\hline Juncaceae (3) & $<$ & 0.2 & 3.4 & 3.0 \\
\hline Luzula arctica & $\ll$ & $<$ & 0.4 & 1.0 \\
\hline Luzula confusa & $<$ & 0.1 & 3.0 & 2.0 \\
\hline Onagraceae (1) & $\ll$ & 0 & 0 & 0 \\
\hline Papaveraceae (1) & 0 & 0 & $\ll$ & $\ll$ \\
\hline Poaceae (9) & 8.7 & 5.0 & 2.7 & 3.4 \\
\hline Anthoxanthum arcticum & 0.5 & $<$ & $\ll$ & $\ll$ \\
\hline Arctagrostis latifolia & 0.6 & $<$ & 0.3 & 3.0 \\
\hline Dupontia fisheri & 7.4 & 4.8 & 1.8 & 0.1 \\
\hline Festuca brachyphylla & $\ll$ & $<$ & 0.4 & $<$ \\
\hline Polygonaceae (2) & $\ll$ & $\ll$ & $<$ & $<$ \\
\hline Pyrolaceae (1) & 0 & 0 & $\ll$ & 0 \\
\hline Ranunculaceae (2) & 0 & 0 & $\ll$ & $\ll$ \\
\hline Rosaceae (2) & 0 & 0 & $<$ & $<$ \\
\hline Salicaceae (4) & 1.2 & 0.9 & 3.4 & 12.6 \\
\hline Salix arctica & 1.2 & 0.9 & 3.1 & 10.8 \\
\hline Salix herbacea & 0 & 0 & $<$ & 0.1 \\
\hline Salix reticulata & $\ll$ & $\ll$ & 0.2 & 1.6 \\
\hline Salix richardsonii & $\ll$ & $\ll$ & $\ll$ & $\ll$ \\
\hline Saxifragaceae (8) & $<$ & 0.2 & 1.5 & $<$ \\
\hline Scrophulariaceae (2) & 0.7 & 0.3 & $<$ & $<$ \\
\hline \multicolumn{5}{|l|}{ Non-vascular taxa } \\
\hline Lichens & $<$ & $<$ & 1.9 & 6.6 \\
\hline Live mosses & 53.1 & 26.6 & 15.9 & 44.6 \\
\hline Drepanocladus spp. & 39.9 & 21.4 & 5.1 & 0 \\
\hline Aulacomnium spp. & 7.5 & 3.2 & 1.4 & 39.3 \\
\hline Dried mosses & 2.9 & 29.6 & 18.2 & 0.9 \\
\hline Fungi & $<$ & 0.2 & 0.1 & $<$ \\
\hline Nostoc spp. & $<$ & $<$ & $\ll$ & $\ll$ \\
\hline Cryptogamic crust & $\ll$ & $<$ & 14.6 & 5.1 \\
\hline
\end{tabular}


Table 3. Canonical correspondence analysis of the vegetation and environmental data gathered in four habitat types in the Qarlikturvik valley, Bylot Island, Nunavut. CCA-1: first canonical axis; CCA-2: second canonical axis.

\begin{tabular}{lrr}
\hline & CCA-1 & CCA-2 \\
\hline Eigenvalues & 0.2208 & 0.1910 \\
Cumulative \% of vegetation data & 7.32 & 13.60 \\
Cumulative \% of vegetation-environment & 42.8 & 79.8 \\
relationship & & \\
Total inertia & 3.0172 & \\
\hline
\end{tabular}

inal polygon microtopography, and decreasing soil moisture and thaw-front depth of disturbed polygons along the gullies. Vegetation was sensitive to this process, and mesic environment plant species gradually replaced hydrophilic species within 5 to 10 years, although the full transition has yet to be reached. This vegetation turn-over can have substantial consequences on wildlife biology, permafrost stabilization and ecosystem-level greenhouse gas emissions (Blok et al., 2010; Doiron et al., 2014; M. T. Jorgenson et al., 2015; McEwing et al., 2015).

\subsection{Transient environmental conditions}

Thermo-erosion gullying led to a significant decrease in soil moisture and thaw-front depth of breached polygons. Both older and recently disturbed polygons had similar soil moisture and thaw-front depth while differing in time since disturbance, which shows that the change in polygon environmental conditions after permafrost disturbance was rapid. The decrease in soil moisture following polygon rim erosion is consistent with what has been previously observed in gullied areas (Seppälä, 1997; Godin and Fortier, 2012a, 2014, 2015; Harms et al., 2014) and concurs with a modeling analysis showing that the transformation of low-centered to highcentered polygon landscape following ice wedge degradation is accompanied by a significant alteration in the water balance partitioning (Liljedahl et al., 2012). In our study, all types of polygons were recharged by snowfall and summer rainfall, yet disturbed habitats had lower soil moisture than wet polygons and a thorough examination of moisture evolution throughout an entire summer showed that soil moisture of breached polygons was significantly more variable than that of wet polygons at both intra- and inter-polygonal scales (Godin et al., 2015). Given that soil moisture is an important driver of plant community composition (Dagg and Lafleur, 2011), it is no surprise that we observed a shift in vegetation following changes in moisture regime.

Decreasing soil moisture in the center of disturbed polygons came with decreasing thaw-front depth, which was expected given that active layer thickness is closely related to soil moisture (Nelson et al., 1999; Hinzman et al., 2005; Minke et al., 2009; Wright et al., 2009; Gangodagamage

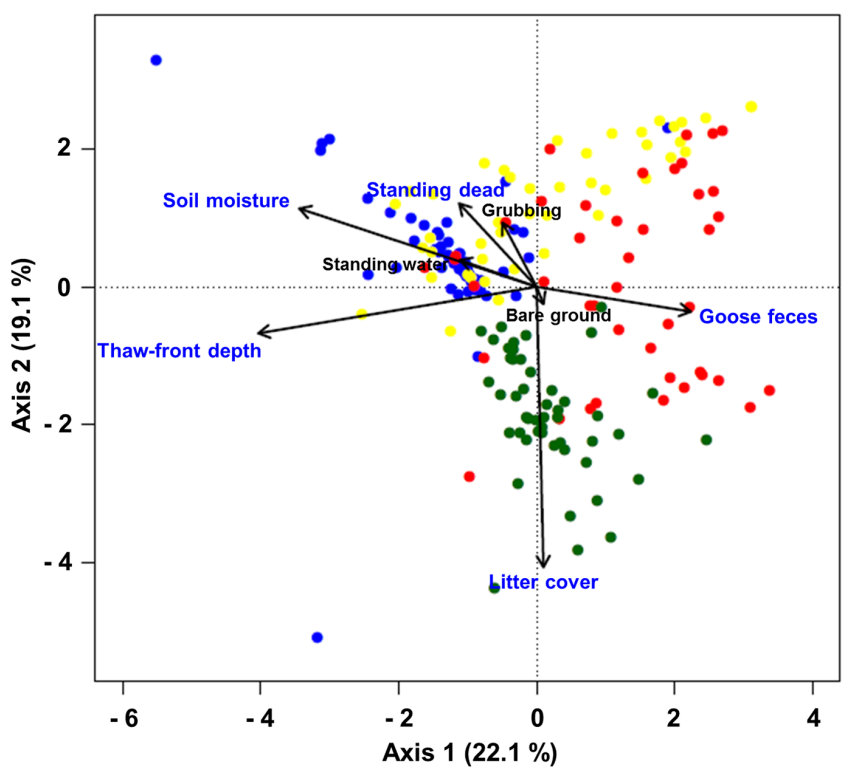

Figure 6. Canonical correspondence analysis ordination diagram of the 197 sites sampled in the Qarlikturvik valley, Bylot Island, Nunavut. Wet polygons $(n=62)$ : blue circles; <5-year disturbed polygons $(n=44)$ : yellow circles; > 5-year disturbed polygons $(n=43)$ : red circles; mesic environments $(n=48)$ : green circles. Blue font indicates statistically significant environmental variables (see Table 4). Standing dead represents the cover of dead attached vascular plants.

et al., 2014). This result, however, contrasts with the active layer thickening generally observed in response to climate warming (Tarnocai et al., 2004; Woo et al., 2007; Akerman and Johansson 2008; Smith et al., 2009; Nauta et al., 2015), and this is likely due in part to ground surface subsidence and drainage which follows ice-rich permafrost thawing (Shiklomanov et al., 2013) and in part to snow accumulation patterns (Godin et al., 2015). Within 5 years of drainage, thaw-front depth in disturbed polygons decreased by $37 \%$ compared to that in wet polygons. This is mainly explained by heat capacity of water and the higher thermal conduction rates in wetter polygons that provide substantial melt energy to the frost table (Nelson et al., 1997; Hinzman et al., 2005; Wright et al., 2009; Romanovsky et al., 2010). This effect is also sharpened by the low thermal conductivity of drier moss carpets in disturbed habitats (Wright et al., 2009) and reduced local snow conditions within the polygons adjacent to the gullies (Godin et al., 2015).

\subsection{Vegetation changes}

Overall, the floristic composition of our sampling sites is in line with previous field surveys conducted in the same area (Gauthier et al., 1996; Duclos, 2002; Doiron, 2014). The presence of Carex aquatilis, Eriophorum scheuchzeri and Dupontia fisheri characterizes well the typical vegeta- 
Table 4. Canonical correspondence analysis of the vegetation sampled along three gullies in the Qarlikturvik valley, Bylot Island, Nunavut, and biplot scores for environmental variables. CCA-1: first canonical axis; CCA-2: second canonical axis. Statistically significant values $(P<0.05)$ after 999 permutations are shown in bold. Standing dead represents the cover of dead attached vascular plants.

\begin{tabular}{llrrrrr}
\hline Environmental variables & $\mathrm{d} f$ & $\chi^{2}$ & $F$ & $P$ & CCA-1 & CCA-2 \\
\hline Litter cover & 1 & 0.1523 & 11.4495 & $\mathbf{0 . 0 0 8}$ & 0.0206 & -0.8681 \\
Thaw-front depth & 1 & 0.1768 & 13.2854 & $\mathbf{0 . 0 0 1}$ & -0.8608 & -0.1436 \\
Soil moisture & 1 & 0.0429 & 3.2206 & $\mathbf{0 . 0 0 2}$ & -0.7339 & 0.2424 \\
Standing dead & 1 & 0.0714 & 5.3688 & $\mathbf{0 . 0 1}$ & -0.2393 & 0.2588 \\
Bare ground & 1 & 0.0065 & 0.4889 & 0.629 & 0.0207 & -0.0522 \\
Standing water & 1 & 0.0090 & 0.6759 & 0.534 & -0.2365 & 0.0830 \\
Grubbing & 1 & 0.0240 & 1.8003 & 0.097 & -0.1051 & 0.1983 \\
Goose feces & 1 & 0.0329 & 2.4717 & $\mathbf{0 . 0 2 8}$ & 0.4769 & -0.0772 \\
Residual & 188 & 2.5014 & & & & \\
\hline
\end{tabular}

tion of Arctic wetlands (Jorgenson et al., 2013; Sandvik and Odland, 2014; Lara et al., 2015) whilst that of Arctagrostis latifolia, Luzula and Salix spp. are common features of Arctic mesic environments (Audet et al., 2007; Sjögersten et al., 2008). Disturbed polygons were the most diverse habitats given that they offered a middle-range state between wet and mesic conditions where hydrophilic species were still present while mesic environment ones had successfully established.

The development of gullies in the Qarlikturvik valley and the subsequent drainage of adjacent low-centered polygons have led within 5 to 10 years to a gradual change in plant communities with vegetation of disturbed polygons leaning toward a new equilibrium, that of mesic environments. Mesic environment species such as Luzula and Salix spp. have established or increased in cover following the decrease in soil moisture and thaw-front depth and replaced hydrophilic Cyperaceae and Poaceae. The secondary succession pioneered here by the gullying process in disturbed polygons follows the directional-species replacement model examined by Svoboda and Henry (1987). However, by occurring within 5 to 10 years, it has been remarkably more rapid than what is usually documented for the High Arctic where perennial plant communities are largely resistant to disturbance (Hollister et al., 2005; Jonsdottir et al., 2005; Hudson and Henry, 2010) and succession dynamics are slow due to short growing seasons and low summer temperatures (Svoboda and Henry, 1987). For instance, plant cover of northeastern Alaska changed little over a 25-year period despite a significant rise in summer temperatures (J. C. Jorgenson et al., 2015). This gradual yet rapid species replacement has been triggered in our system by the hydrological and thermal shift caused by gullying and favored by the mosaic of wet and mesic habitats allowing for a substantial pool of species with both vegetative and sexual reproduction.

In the canonical ordination analysis, the soil moisture gradient discriminated wet polygons from the other habitats as well as recently disturbed from older disturbed habitats. The $37 \%$ decrease in soil moisture between wet and disturbed polygons represents a drastic change of conditions for plant communities and is of similar magnitude than what has been documented in Alaskan drying wetlands as a result of increasing temperatures (Klein et al., 2005). The strong influence of soil moisture in separating plant community types at high latitudes has indeed been well documented (Hinzman et al., 2005; Daniëls and de Molenaar, 2011; Daniëls et al., 2011; Sandvik and Odland, 2014). Four other variables significantly influenced the distinction among habitats: (i) thaw-front depth discriminated habitats in the same direction than soil moisture with a $30 \%$ decrease in disturbed polygons and mesic environments compared to wet polygons, which was expected since these two factors are closely related (see Sect. 4.1); (ii) litter cover separated mesic environments from the others, which may be explained by increased organic matter related to greater shrub abundance in mesic environments (Zamin et al., 2014); (iii) vascular plant standing dead separated wet and recently disturbed polygons from the other habitats, which can be explained by the senescence of Cyperaceae tillers that are highly abundant at these locations (Fig. 5); (iv) goose feces were mainly associated with older disturbed and mesic environments. While this may suggest a higher use of these habitats by geese, the slower degradation of feces in dryer habitats cannot be ruled out; this has yet to be tested.

The shift in vegetation composition in disturbed polygons was accompanied by significant changes in biomass. Aboveground biomass of graminoids was the greatest in wet polygons, which is concordant with the fact that wetlands are the most productive habitats of forage plants in the Arctic (Sheard and Geale, 1983; Duclos, 2002; Doiron, 2014). It gradually decreased in disturbed polygons as conditions became closer to those of mesic environments. Compared to the immediate change in environmental conditions, we nonetheless observed a lag-time in vegetation response to thermo-erosion related disturbances as graminoid biomass differed significantly between recently and older disturbed polygons. In our study, graminoid above-ground biomass of wet polygons was $35 \%$ lower than what Cadieux et al. (2008) found via a long-term plant monitoring on By- 
lot Island $\left(45.2 \mathrm{~g} \mathrm{~m}^{-2}\right)$, and $62.7 \%$ lower than what Gauthier et al. (2012) measured in the most productive wetlands of the Qarlikturvik Valley $\left(78.4 \pm 10.5 \mathrm{~g} \mathrm{~m}^{-2}\right)$. These contrasts may be explained by varying species composition and to a lesser extent by earlier plant harvesting in our case. Indeed, while we focused on wet polygons dominated by Carex aquatilis, Cadieux et al. (2008) and Gauthier et al. (2012) worked on wet polygons dominated by Dupontia fisheri and Eriophorum scheuchzeri. Because our study was part of a large-scale multisite project on wetland carrying capacity for snow geese (Legagneux et al., 2012; Doiron, 2014), we only focused on forage plant (i.e. graminoids) biomass and did not sample forbs or shrubs. Since above-ground biomass of graminoids account for more than 90 per cent of vascular plant biomass in wetlands (Gauthier et al., 1995), we provide here an accurate estimate of the total above-ground biomass that can be found in these habitats. However, the total aboveground biomass in mesic environments was probably underestimated. For instance, biomass of shrubs and forbs respectively ranged between 22 and $48 \mathrm{~g} \mathrm{~m}^{-2}$ and between 6 and $20 \mathrm{~g} \mathrm{~m}^{-2}$ in the mesic environments adjacent to our study area (E. Lévesque, unpublished data). Overall, total aboveground biomass in wetlands and mesic environments is of similar order of magnitude $\left(50.5 \mathrm{~g} \mathrm{~m}^{-2} \pm 2.8 \mathrm{SE}\right.$ in wetlands and $44.2 \mathrm{~g} \mathrm{~m}^{-2} \pm 6.8$ SE in mesic tundra for the period $2007-$ 2009; Legagneux et al., 2012).

\subsection{Impacts on ecosystems}

It is likely that the replacement of hydrophilic plants by mesic vegetation will severely impact wildlife biology. The Qarlikturvik valley of Bylot Island represents an important summer habitat for greater snow geese (Legagneux et al., 2012). It is well documented that this species mostly relies on wetlands for food resources (Gauthier et al., 1995, 2011), especially because graminoids are easily digested due to their low fiber concentration and rich nutritive elements (Sedinger and Raveling, 1989; Manseau and Gauthier, 1993; Audet et al., 2007). For instance, geese removed respectively 40 and $31 \%$ of the total annual production of Dupontia fisheri and Eriophorum scheuchzeri during the period 1990-2007 (Cadieux et al., 2008). It remains to quantify the extent to which gullying alters wetland carrying capacity. In addition, the presence of ponds in wetlands provides geese refuges from predators such as the arctic fox (Hughes et al., 1994; Lecomte et al., 2009), and their disappearance might also change predator-prey interactions.

Effects of gullying-induced vegetation changes may finally be visible on variations of greenhouse gas emissions. There is evidence for a strong vegetation control on methane emission from wetlands (Olefeldt et al., 2013; Lara et al., 2015; McEwing et al., 2015; Tveit et al., 2015). In wet polygonal tundra of Northern Siberia, Kutzbach et al. (2004) found for instance that dense Carex aquatilis stands emitted more methane than sites with low Carex densities. Overall, wet- land and lake expansion are thought to increase methane emission but also carbon storage (Myers-Smith, 2005; Nauta et al., 2015; Treat et al., 2015; Bouchard et al., 2015). We can therefore expect that the reverse transition from wet to mesic environments observed within our low-centered polygon landscape would lead to reduced methane emission and increased $\mathrm{CO}_{2}$ emission through enhanced decomposition. However, no general pattern on ecosystem responses to decreased water table position and subsequent gas emissions has emerged to date (see Grosse et al., 2011 for review). It will thus be crucial to determine in the near future the specific evolution of Salix and Luzula spp. primary production in mesic environments in order to accurately predict the effects of wetland retreat on methane and soil organic carbon cycles.

\section{Conclusions}

This study illustrates that changes in the hydrological and thermal regimes following thermo-erosion gullying processes boost landscape transformation from wet to mesic habitats, providing evidence that permafrost disturbance is a critical component of ecosystem modification at high latitudes. Ecological studies should consequently start using an approach that integrates disturbed permafrost monitoring if one wants to more efficiently document climate change effects on arctic terrestrial ecosystems. In addition, our latest field observations showed that hydrology and thaw regimes of breached polygons have yet to reach equilibrium with new conditions. Similarly, vegetation remains in transition given that, 10 years after disturbance, the cover of dominant shrubs and mesic bryophytes in disturbed polygons is still lower than in adjacent mesic environments. It is currently not possible to predict how long these species would take to out compete declining species and cryptogamic crust and reach a new mesic environment equilibrium. This current state underscores the importance of long-term monitoring of permafrost and its associated vegetation. In addition, more work should be devoted to the feedback effects of plant communities and vegetation succession on thermal and mechanical stabilization dynamics of disturbed permafrost terrains. This is especially needed since plant community differences between disturbed and intact sites can last several centuries (Cray and Pollard, 2015). 


\section{Appendix A}

Table A1. Sample sizes and means $( \pm \mathrm{SE})$ of soil moisture, thaw-front depth and graminoid above-ground biomass in the four habitats studied in the Qarlikturvik valley of Bylot Island, Nunavut. Letters refer to post hoc contrasts that were carried out using the LSMEANS statement and Bonferroni adjustment (procedure MIXED, SAS 9.4). For a given variable, different letters indicate significant differences among habitats.

\begin{tabular}{|c|c|c|c|c|c|c|c|c|c|c|}
\hline \multirow[t]{2}{*}{ Habitats } & \multicolumn{2}{|c|}{$\begin{array}{l}\text { Soil moisture } \\
5 \mathrm{Jul} 2010(\%)\end{array}$} & \multicolumn{2}{|c|}{$\begin{array}{l}\text { Soil moisture } \\
30 \mathrm{Jul} 2010(\%)\end{array}$} & \multicolumn{2}{|c|}{$\begin{array}{l}\text { Thaw-front depth } \\
\text { Jul } 2009(\mathrm{~cm})\end{array}$} & \multicolumn{2}{|c|}{$\begin{array}{l}\text { Thaw-front depth } \\
\text { Jul } 2010(\mathrm{~cm})\end{array}$} & \multicolumn{2}{|c|}{$\begin{array}{c}\text { Above-ground } \\
\text { biomass }\left(\mathrm{g} \mathrm{m}^{-2}\right)\end{array}$} \\
\hline & $n$ & Mean \pm SE & $n$ & Mean \pm SE & $n$ & Mean \pm SE & $n$ & Mean \pm SE & $n$ & Mean \pm SE \\
\hline Wet polygons & 53 & $36.3 \pm 1.7 \mathrm{a}$ & 54 & $48.0 \pm 1.3 \mathrm{a}$ & 52 & $36.0 \pm 0.9 \mathrm{a}$ & 62 & $34.6 \pm 0.8 \mathrm{a}$ & 5 & $29.2 \pm 5.2 \mathrm{a}$ \\
\hline$<5$-year disturbed polygons & 39 & $21.9 \pm 1.2 \mathrm{~b}$ & 39 & $31.0 \pm 1.5 b$ & 39 & $25.5 \pm 1.5 b$ & 44 & $25.0 \pm 1.1 \mathrm{~b}$ & 5 & $22.3 \pm 1.4 \mathrm{a}$ \\
\hline$>5$-year disturbed polygons & 33 & $22.0 \pm 1.1 \mathrm{~b}$ & 33 & $31.2 \pm 1.2 \mathrm{~b}$ & 32 & $25.3 \pm 1.1 b$ & 43 & $24.9 \pm 0.8 b$ & 5 & $9.3 \pm 4.0 \mathrm{~b}$ \\
\hline Mesic environments & 46 & $19.6 \pm 1.3 b$ & 50 & $28.4 \pm 1.4 \mathrm{~b}$ & 44 & $27.6 \pm 1.1 \mathrm{~b}$ & 48 & $26.5 \pm 0.7 \mathrm{~b}$ & 5 & $5.9 \pm 2.6 \mathrm{~b}$ \\
\hline
\end{tabular}


Table A2. List of the vascular plant species inventoried in the Qarlikturvik valley, Bylot Island, Nunavut during the 2009 and 2010 field seasons. Species names were retrieved (2011) from the Integrated Taxonomic Information System (ITIS) (http://www.itis.gov).

\begin{tabular}{|c|c|}
\hline Family & Species \\
\hline Asteraceae & $\begin{array}{l}\text { Erigeron uniflorus var. eriocephalus (Vahl) Boivin, Taraxacum hy- } \\
\text { parcticum Dahlst., Tephroseris palustris (L.) Reichenbach }\end{array}$ \\
\hline Brassicaceae & $\begin{array}{l}\text { Cardamine bellidifolia L., Cardamine nymanii Gand., Draba cinerea } \\
\text { Adams, Draba corymbosa } \mathrm{R} \text {. Br., Draba glabella } \text { Pursh, Draba lactea } \\
\text { Adams, Draba nivalis Lilj., Draba sp. }{ }^{*} \text {, Eutrema edwardsii R. Br. }\end{array}$ \\
\hline Caryophyllaceae & $\begin{array}{l}\text { Cerastium alpinum L. s. lat., Minuartia rubella (Wahlenb.) Hiern., } \\
\text { Silene involucrata (Cham. \& Schlecht.) Bocquet subsp. involucrate, } \\
\text { Silene uralensis (Rupr.) Bocquet subsp. uralensis, Stellaria longipes } \\
\text { Goldie subsp. longipes }\end{array}$ \\
\hline Cyperaceae & $\begin{array}{l}\text { Carex aquatilis var. minor Boott, Carex marina Dewey, Eriophorum } \\
\text { angustifolium Honck subsp. angustifolium, Eriophorum scheuchzeri } \\
\text { Hoppe s. lat./ russeolum subsp. leiocarpum Novos. }\end{array}$ \\
\hline Equisetaceae & Equisetum arvense L. s. lat. \\
\hline Ericaceae & Cassiope tetragona var. tetragona $(\mathrm{L}$.$) Don$ \\
\hline Fabaceae & $\begin{array}{l}\text { Astragalus alpinus var. alpinus L. Oxytropis maydelliana ssp. } \\
\text { Melanocephala (Hook.) Porsild }\end{array}$ \\
\hline Juncaceae & Juncus biglumis L., Luzula arctica Blytt, Luzula confusa Lindebl. \\
\hline Onagraceae & Epilobium arcticum Sam. \\
\hline Papaveraceae & $\begin{array}{l}\text { Papaver sp. (including P. dahlianum, P. cornwalissense, P. lapponicum } \\
\text { ssp. occidentale) }\end{array}$ \\
\hline Poaceae & $\begin{array}{l}\text { Alopecurus borealis Trin., Anthoxanthum arcticum Veldkamp, Arcta- } \\
\text { grostis latifolia subsp. latifolia (R. Br.) Griseb., Deschampsia brevifolia } \\
\text { R. Br., Dupontia fisheri R. Br., Festuca brachyphylla ssp. brachyphylla } \\
\text { Schult. \& Schult. f., Phippsia algida (Sol.) R. Br., Pleuropogon sabinei } \\
\text { R. Br., Poa arctica R. Br. s. lat. }\end{array}$ \\
\hline Polygonaceae & Bistorta vivipara (L.) Delarbre, Oxyria digyna (L.) Hill \\
\hline Pyrolaceae & Pyrola grandiflora Radius \\
\hline Ranunculaceae & Ranunculus hyperboreus Rottb., Ranunculus nivalis L. \\
\hline Rosaceae & $\begin{array}{l}\text { Dryas integrifolia Vahl subsp. integrifolia, Potentilla hyparctica Malte } \\
\text { subsp. hyparctica }\end{array}$ \\
\hline Salicaceae & $\begin{array}{l}\text { Salix arctica Pall., Salix herbacea L., Salix reticulata L., Salix richard- } \\
\text { sonii Hook. }\end{array}$ \\
\hline Saxifragaceae & $\begin{array}{l}\text { Chrysosplenium tetrandrum (Lund) Th. Fries, Micranthes foliolosa (R. } \\
\text { Br.) Gornall, Micranthes hieraciifolia (Waldst. \& Kit.) Haworth, Mi- } \\
\text { cranthes nivalis (L.) Small, Saxifraga cernua L., Saxifraga cespitosa } \\
\text { L., Saxifraga hirculus L., Saxifraga oppositifolia L. }\end{array}$ \\
\hline Scrophulariaceae & $\begin{array}{l}\text { Pedicularis langsdorfii subsp. arctica (R. Br.) Pennell, Pedicularis sude- } \\
\text { tica subsp. albolabiata Hult. }\end{array}$ \\
\hline
\end{tabular}

* Draba sp. was not counted as a distinct species because it is probably one of the five species already mentioned. 
Acknowledgements. The authors are grateful to the Inuit community of Pond Inlet and to Parks Canada-Sirmilik National Park, Centre d'études nordiques (CEN) and Gilles Gauthier (Université Laval) for the access to the field camp during summers 2009, 2010 and 2012. We also thank Alexandre Guertin-Pasquier, Étienne Godin, Jonathan Lasnier, Stéphanie Coulombe and Coralie Henry-Brouillette for their fieldwork support as well as Alexandre Moreau, Stephan Ouellet, Noémie Boulanger-Lapointe for their help with statistical analyses. This project was funded by the International Polar Year program of the Government of Canada, Fonds Québécois de la Recherche sur la Nature et les Technologies (FQRNT), Natural Sciences and Engineering Research Council of Canada (NSERC) Discovery Frontiers grant "Arctic Development and Adaptation to Permafrost in Transition" (ADAPT), Network of Centers of Excellence of Canada ArcticNet, Northern Scientific Training Program (NSTP), NSERC CREATE Training Program in Northern Environmental Sciences (EnviroNorth), Groupe de Recherche en Biologie Végétale (GRBV) of Université du Québec à Trois-Rivières and Cold Regions Geomorphology and Geotechnical Laboratory (Geocryolab) of Université de Montréal. Essential logistic support was provided by Polar Continental Shelf Program (Natural Resources Canada).

Edited by: W. F. Vincent

\section{References}

Akerman, H. J. and Johansson, M.: Thawing permafrost and thicker active layer in sub-arctic Sweden, Permafrost Periglac., 19, 279292, 2008

Allard, M.: Geomorphological changes and permafrost dynamics: key factors in changing arctic ecosystems, An example from Bylot Island, Nunavut, Canada, Geosci. Can., 23, 205-212, 1996.

Audet, B., Lévesque, E., and Gauthier G.: Seasonal variation in plant nutritive quality for Greater Snow Goose goslings in mesic tundra, Can. J. Bot., 85, 457-462, 2007.

Avis, C. A., Weaver, A. J., and Meissner, K. J.: Reduction in areal extent of high-latitude wetlands in response to permafrost thaw, Nat. Geosci., 4, 444-448, 2011.

Beck, I., Ludwig, R., Bernier, M., Lévesque, E., and Boike, J.: Assessing permafrost degradation and land cover changes (1986-2009) using remote sensing data over Umiujaq, sub-Arctic Québec, Permafrost Periglac., 26, 129-141, doi:10.1002/ppp.1839, 2015.

Beilman, D. W. and Robinson, S. D.: Peatland permafrost thaw and landform type along a climate gradient, in: Proceedings, Eigth International Conference on Permafrost, edited by: Phillips, M., Springman, P. M., and Arenson, S. U., A. A. Balkema, Zurich, Switzerland, 1, 61-65, 2003.

Blok, D., Heijman, M. M. P. D., Schaepman-Strub, G., Kononov, A. V., Maximov, T. C., and Berendse, F.: Shrub expansion may reduce summer permafrost thaw in Siberia tundra, Glob. Change Biol., 16, 1296-1305, 2010.

Bouchard, F., Laurion, I., Preskienis, V., Fortier, D., Xu, X., and Whiticar, M. J.: Modern to millennium-old greenhouse gases emitted from freshwater ecosystems of the Eastern Canadian Arctic, Biogeosciences, 12, 7279-7298, doi:10.5194/bg-127279-2015, 2015.
Cadieux, M.-C., Gauthier, G., Gagnon, C. A., Lévesque, E., Bêty, J., and Berteaux, D.: Monitoring the environmental and ecological impacts of climate change on Bylot Island, Sirmilik National Park, Université Laval, 113 pp., 2008.

Chen, Z. H., Chen, W. J., Leblanc, S. G., and Henry, G. H. R.: Digital photograph analysis for measuring percent plant cover in the Arctic, Arctic, 63, 315-326, doi:10.14430/arctic1495, 2010.

Christiansen, H. H., Eltzelmuller, B., Isaksen, K., Juliussen, H., Farbrot, H., Humlum, O., Johansson, M., Ingeman-Nielsen, T., Kristensen, L., Hjort, J., Holmlund, P., Sannel, A. B. K., Sigsgaard, C., Åkerman, H. J., Foged, N., Blikra, L. H., Pernosky, M. A., and Ødegård, R. S.: The thermal state of permafrost in the Nordic Area during the International Polar Year 2007-2009, Permafrost Periglac., 21, 156-181, 2010.

Collins, M., Knutti, R., Arblaster, J., Dufresne, J.-L., Fichefet, T., Friedlingstein, P., Gao, X., Gutowski, W. K., Johns, T., Krinner, G., Shongwe, M., Tebaldi, C., Weaver, A. J., and Wehner, M.: Long-term climate change: Projections, commitments and irreversibility, in: Climate change 2013: the physical basis, Contribution of working group I to the Fifth Assessment Report of the Intergovernmental Panel on Climate Change, edited by: Stocker, T. F., Qin, D., Plattner, G.-K., Tignor, M., Allen, S. K., Boschung, J., Nauels, A., Xia, Y., Bex, V., and Midgley, P. M., Cambridge University Press, Cambridge, United Kingdom, 2013.

Cray, H. A. and Pollard, W. H.: Vegetation recovery patterns following permafrost disturbance in a Low Arctic setting: case study of Herschel Island, Yukon, Canada, Arct. Antarct. Alp. Res., 47, 99-113, 2015.

Dagg, J. and Lafleur, P.: Vegetation community, foliar nitrogen, and temperature effects on tundra $\mathrm{CO}_{2}$ exchange across a soil moisture gradient, Arct. Antarct. Alp. Res., 43, 189-197, 2011.

Daniëls, F. J. A. and de Molenaar, J. G: Flora and vegetation of Tasiilaq, formerly Angmagssalik, southeast Greenland: a comparison of data between around 1900 and 2007, Ambio, 40, 650-659, 2011.

Daniëls, F. J. A., de Molenaar, J. G., Chytrý, M., and Tichý, T.: Vegetation change in southeast Greenland? Tasiilaq revisited after 40 years, J. Appl. Veg. Sci., 14, 230-241, 2011.

Daubenmire, R.: A canopy-coverage method of vegetationnal analysis, Northwest Sci., 33, 43-64, 1959.

Doiron, M.: Impacts des changements climatiques sur les relations plantes-herbivores dans l'Arctique, $\mathrm{PhD}$ thesis, Université Laval, 123 pp., 2014.

Doiron, M., Gauthier, G., and Lévesque, E.: Effects of experimental warming on nitrogen concentration and biomass of forage plants for an arctic herbivore, J. Ecol., 102, 508-517, 2014.

Duclos, I.: Milieux mésiques et secs de l'Île Bylot, Nunavut (Canada): caractérisation et utilisation par la Grande Oie des Neiges. MSc thesis, Université du Québec à Trois-Rivières, Trois-Rivières, 113 pp., 2002.

Ellis, C. J. and Rochefort, L.: Century-scale development of polygon-patterned tundra wetland, Bylot Island $\left(73^{\circ} \mathrm{N}, 80^{\circ} \mathrm{W}\right)$, Ecology, 4, 963-978, 2004.

Ellis, C. J., Rochefort, L., Gauthier, G., and Pienitz, R.: Paleoecological evidence for transitions between contrasting landforms in a polygon-patterned High Arctic wetland, Arct. Antarct. Alp. Res., 40, 624-637, 2008. 
Epstein, H. E., Myers-Smith, I., and Walker, D. A.: Recent dynamics of arctic and sub-arctic vegetation, Environ. Res. Lett., 8, 015040, doi:10.1088/1748-9326/8/1/015040, 2013.

Fortier, D. and Allard, M.: Late Holocene syngenetic icewedge polygons development, Bylot Island, Canadian Arctic Archipelago, Can. J. Earth Sci., 41, 997-1012, 2004.

Fortier, D. and Allard, M.: Frost-cracking conditions, Bylot Island, Eastern Canadian Arctic archipelago, Permafrost Periglac., 16, 145-161, 2005.

Fortier, D., Allard, M., and Pivot, F.: A late-Holocene record of loess deposition in ice-wedge polygons reflecting wind activity and ground moisture conditions, Bylot Island, eastern Canadian Arctic, Holocene, 16, 635-646, 2006.

Fortier, D., Allard, M., and Shur, Y.: Observation of rapid drainage system development by thermal erosion of ice wedges on Bylot Island, Canadian Arctic Archipelago, Permafrost Periglac., 18, 229-243, 2007.

Gangodagamage, C., Rowland, J. C., Hubbard, S. S., Brumby, S. P., Liljedahl, A. K., Wainwright, H., Wilson, C. J., Altmann, G. L., Dafflon, B., Peterson, J., Ulrich, C., Tweedie, C. E., and Wullschleger, S. D: Extrapolating active layer thickness measurements across Arctic polygonal terrain using LiDAR and NDVI data sets, Water Resour. Res., 8, 19 pp., doi:10.1002/2013WR014283, 2014.

Gauthier, G., Hughes, R. J., Reed, R., Beaulieu, J., and Rochefort, L.: Effect of grazing by greater snow geese on the production of graminoids at an arctic site (Bylot Island, NWT, Canada), J. Ecol., 83, 653-664, 1995.

Gauthier, G., Rocheford, L., and Reed, A.: The exploitation of wetland ecosystems by herbivores on Bylot Island, Geosci. Can., 23, 253-259, 1996.

Gauthier, G., Cadieux, M.-C., Lefebvre, J., Bêty, J., and Berteaux D.: Population study of Greater Snow Geese and its nesting habitat on Bylot Island, Nunavut, in 2009: A progress report, 31 pp., 2009.

Gauthier, G., Cadieux, M.-C., Lefebvre, J., Bêty, J., and Berteaux D. Population study of Greater Snow Geese and its nesting habitat on Bylot Island, Nunavut, in 2010: A progress report, 32 pp., 2010.

Gauthier, G., Berteaux D., Bêty, J., Tarroux, A., Therrien, J.-F., McKinnon, L., Legagneux, P., and Cadieux, M.-C.: The tundra food web of Bylot Island in a changing climate and the role of exchanges between ecosystems, Ecoscience, 18, 223-235, 2011.

Gauthier, G., Cadieux, M.-C., Lefebvre, J., Bêty, J., and Berteaux D. Population study of Greater Snow Geese and its nesting habitat on Bylot Island, Nunavut, in 2012: A progress report, 36 pp., 2012.

Gauthier, G., Bêty, J., Cadieux, M.-C., Legagneux, P., Doiron, M., Chevallier, C., Lai, S., Tarroux, A., and Berteaux D.: Long-term monitoring at multiple trophic levels suggests heterogeneity in responses to climate change in the Canadian Arctic tundra, Phil. Trans. R Soc. B, 368, 20120482, doi:10.1098/rstb.2012.0482, 2013.

Godin, E. and Fortier, D.: Geomorphology of thermo-erosion gullies - case study from Bylot Island, Nunavut, Canada, in: Proceedings, 6th Canadian Permafrost Conference and 63rd Canadian Geotechnical Conference, Calgary, 2010.

Godin, E. and Fortier, D.: Fine scale spatio-temporal monitoring of multiple thermo-erosion gullies development on Bylot Island, eastern canadian archipelago, in: Proceedings, Tenth International Conference on Permafrost (TICOP), Salekhard, Russia, 7 pp., doi:10.13140/2.1.3827.6803, 2012a.

Godin, E. and Fortier, D.: Geomorphology of a thermo-erosion gully, Bylot Island, Nunavut, Canada, Can. J. Earth Sci., 49, 979986, 2012 b.

Godin, E., Fortier, D., and Coulombe, S.: Effects of thermoerosion gullying on hydrologic flow networks, discharge and soil loss, Environ. Res. Lett., 10, 10 pp., doi:10.1088/17489326/9/10/105010, 2014.

Godin, E., Fortier, D., and Lévesque, E.: Nonlinear thermal and moisture dynamics of high Arctic wetland polygons following permafrost disturbance, Biogeosciences Discuss., 12, 1179711831, doi:10.5194/bgd-12-11797-2015, 2015.

Grosse, G., Harden, J., Turetsky, M., McGuire A. D., Camill, P., Tarnocai, C., Frolking, S., Schuur, E. A. G., Jorgenson, T., Marchenko, S., Romanovsky, V., Wickland, K. P., French, N., Waldrop, M., Bourgeau-Chavez, L., and Striegl, R. G.: Vulnerability of high-latitude soil organic carbon in North America to disturbance, J. Geophys. Res., 116, G00K06, doi:10.1029/2010JG001507, 2011.

Gruyer, N. G., Gauthier, G., and Berteaux, D.: Cyclic dynamics of sympatric lemming populations on Bylot Island, Nunavut, Canada, Can. J. Zool., 86, 910-917, 2008.

Günther, F., Overduin, P. P., Sandakov, A. V., Grosse, G., and Grigoriev, M. N.: Short- and long-term thermo-erosion of ice-rich permafrost coasts in the Laptev Sea region, Biogeosciences, 10, 4297-4318, doi:10.5194/bg-10-4297-2013, 2013.

Harms, T. K., Abbott, B. W., and Jones, J. B.: Thermo-erosion gullies increase nitrogen available for hydrologic export, Biogeochemisty, 117, 299-311, 2014.

Hinzman, L. D., Bettez, N. D., Bolton, W. R., Chapin III, F. S., Dyurgerov, M. B., Fastie, C. L., Griffith, B., Hollister, R. D., Hope, A., Huntington, H. P., Jensen, A. M., Jia, Gensuo, J. J., Jorgenson, T., Kane, D. L., Klein, D. R., Kofinas, G., Lynch, A. H., Lloyd, A. H., McGuire, A. D., Nelson, F. E., Oechel, W. C., Osterkamp, T. E., Racine, C. H., Romanovsky, V. E., Stone, R. S., Stow, D. A., Sturm, M., Tweedie, C. E., Vourlitis, G. L., Walker, M. D., Walker, D. A., Webber, P. J., Welker, J. M., Winker, K. S., and Yoshikawa, K.: Evidence and implications of recent climate change in northern Alaska and other arctic regions, Clim. Change, 72, 251-298, 2005.

Hollister, R. D., Webber, P. J., and Tweedie, C. E.: The response of Alaskan arctic tundra to experimental warming: differences between short- and long-term responses, Glob. Change Biol., 11, 525-536, 2005.

Hudson, J. M. G. and Henry, G. H. R.: High Arctic plant community resists 15 years of experimental warming, J. Ecol., 98, 10351041, 2010.

Hughes, R. J., Reed, A., and Gauthier, G. Space and habitat use by greater snow goose broods on Bylot Island, Northwest Territories, J. Wildlife Manage., 58, 536-545, 1994.

IPY, International Polar Year: Climate Change Impact on Canadian Arctic Tundra, Protocols for taking vertical photographs and field measurements of plant height for biomass and LAI estimation in Arctic tundra (for vegetation height $<0.5 \mathrm{~m}$ ), Protocols for taking vertical photographs and field measurements of plant height for biomass and LAI estimation in Arctic tundra (for vegetation height $<0.5 \mathrm{~m}$ ), http://ipytundra.ca/protocols, 2012. 
Jonsdottir, I. S., Magnusson, B., Gudmunsson, J., Elmarsdottir, A., and Hjartarson, H.: Variable sensitivity of plant communities in Iceland to experimental warming, Glob. Change Biol., 11, 553563, 2005.

Jorgenson, J. C., Raynolds, M. K., Reynolds, J. H., and Benson, AM.: Twenty-five year record of changes in plant cover on tundra of northeastern Alaska, Arct. Antarct. Alp. Res., 47, 785-806, 2015.

Jorgenson, M. T., Shur, Y. T., and Pullman, E. R.: Abrupt increase in permafrost degradation in Arctic Alaska, Geophys. Res. Lett., 33, L02503, doi:10.1029/2005GRL024960, 2006.

Jorgenson, M. T., Romanosky, V., Harden, S., Shur, Y., O’Donnell, J., Schuur E. A. G., Kanevskiy, M., and Marchenko, S.: Resilience and vulnerability of permafrost to climate change, Can. J. For. Res., 40, 1219-1236, 2010.

Jorgenson, M. T., Harden, S., Kanevskiy, M., O’Donnell, J., Wickland, K., Ewing, S., Manies, K., Zhuang, Q., Shur, Y., Striegl, R., and Koch, J.: Reorganization of vegetation, hydrology and soil carbon after permafrost degradation across heterogeneous boreal landscapes, Environ. Res. Lett., 8, 3, doi:10.1088/17489326/9/10/105010, 2013.

Jorgenson, M. T., Kanevskiy, M., Shur, Y., Moskalenko, N., Brown, D. R. N., Wickland, K., Striegl, R., and Koch, J.: Role of ground ice dynamics and ecological feedbacks in recent ice wedge degradation and stabilization, J. Geophys. Res. Earth Surf., 120, 2280-2297, 2015.

Klein, E., Berg, E. E., and Dial, R.: Wetland drying and succession across the Kenai Peninsula Lowlands, south-central Alaska, Can. J. For. Res., 35, 1931-1941, 2005

Kokelj, S. V., Lantz, T. C., Wolfe, S. A., Kanigan, J. C., Morse, P. D., Coutts, R., Molina-Giraldo, N., and Burn, C. R.: Distribution and activity of ice wedges across the forest-tundra transition, western Arctic Canada, J. Geophys. Res. Earth Surf., 119, 9, doi:10.1002/2014JF003085, 2014.

Kutzbach, H. J., Wagner, D., and Pfeiffer, E. M.: Effect of microrelief and vegetation on methane emission wet polygonal tundra, Lena Delta, Northern Siberia, Biogeochemistry, 69, 341-362, 2004.

Lara, M. J., McGuire, A. D., Euskirchen, E. S., Tweedie, C. E., Hinkel, K. M., Skurikhin, A. N., Romanovsky, V. E., Grosse, G., Bolton, W. R., and Genet, H.: Polygonal tundra geomorphological change in response to warming alters future $\mathrm{CO}_{2}$ and $\mathrm{CH}_{4}$ flux on the Barrow Peninsula, Glob. Change Biol., 21, 16341651, doi:10.1111/gcb.12757, 2015.

Lecomte, N., Gauthier, G., and Giroux, J.-F.: A link between water availability and nesting success mediated by predator-prey interactions in the Arctic, Ecology, 90, 465-475, 2009.

Legagneux, P., Gauthier, G., Berteaux, D., Bêty, J., Cadieux, M.-C., Bilodeau, F., Bolduc, E., McKinnon, L., Tarroux, A., Therrien, J.-F., Morissette, L., and Krebs, C. J.: Disentangling trophic relationships in a High Arctic tundra ecosystem through food web modeling, Ecology, 93, 1707-1716, 2012.

Levy, J. S., Head, J. W., and Marchant, D. R.: The role of thermal contraction crack polygons in cold-desert fluvial systems, Antarct. Sci., 20, 565-579, 2008.

Liljedahl, A. K., Hinzman, L. D., and Schulla, J.: Ice-wedge polygon type controls low-gradient watershed-scale hydrology, in: Proceedings, Tenth International Conference on Permafrost (TICOP), Salekhard, Russia, 6 pp., 2012.
Littell, R. C., Milliken, G. A., Stroup, W. W., Wolfinger, R. D., and Schabenberger, O.: SAS ${ }^{\circledR}$ for Mixed Models, 2nd Edn., SAS Institute Inc, Cary, NC, 2006.

Manseau, M. and Gauthier, G.: Interactions between greater snow geese and their rearing habitat, Ecology, 74, 2045-2055, 1993.

Massé, H., Rochefort, L., and Gauthier, G.: Carrying capacity of wetland habitats used by breeding greater snow geese, J. Wildlife Manage., 65, 271-281, 2001.

McEwing, K. R., Fisher, J. P., and Zona, D.: Environmental and vegetation controls on the spatial variability of $\mathrm{CH}_{4}$ emission from wet-sedges and tussock tundra ecosystems in the Arctic, Plant Soil, 338, 37-52, 2015.

Minke, M., Donner, D., Karpov, N. S., de Klerk, P., and Joosten, H.: Distribution, diversity, development and dynamics of polygon mires: examples from Northeast Yakutia (Siberia), Peatlands Int., 1, 36-40, 2007.

Minke, M., Donner, D., Karpov, N. S., de Klerk, P., and Joosten, H.: Patterns in vegetation composition, surface height and thaw depth in polygon mires in the Yakutian Arctic (NE Siberia): a microtopographical characterisation of the active layer, Permafrost Periglac., 20, 357-368, 2009.

Myers-Smith, I. H.: Carbon exchange and permafrost collapse: implications for a changing climate, MSc thesis, University of Alaska Fairbanks, Fairbanks, 66 pp., 2005.

Naito, A. T. and Cairns, D. M.: Patterns of shrub expansion in Alaskan arctic river corridors suggest phase transition, Ecol. Evol., 5, 87-101, 2015.

Natali, S. M., Schuur, E. A. G., Mauritz, M., Schade, J. D., Celis, G., Crummer, K. G., Johnston, C., Krapek, J., Pegoraro, E., Salmon, V. G., and Webb, E. E.: Permafrost thaw and soil moisture driving $\mathrm{CO}_{2}$ and $\mathrm{CH}_{4}$ release from upland tundra, J. Geophys. Res. Biogeosci., 120, 525-537, doi:10.1002/2014JG002872, 2015.

Nauta, A. L., Heijmans, M. M. P. D., Blok, D., Limpens, J., Elberling, B., Gallagher, A., Li, B., Petrov, R. E., Maximov, T. C., van Huissteden, J., and Berendse, F.: Permafrost collapse after shrub removal shifts tundra ecosystem to a methane source, Nature Clim. Change, 5, 67-70, 2015.

Nelson, F. E., Shiklomanov, N. I., and Mueller, G. R.: Variability of active-layer thickness at multiple spatial scales, North-central Alaska, USA, Arct. Antarct. Alp. Res., 31, 179-186, 1999.

Nelson, F. E., Shiklomanov, N. I., Hinkel, K. M., and Brown J.: Decadal results from the Circumpolar Active Layer Monitoring (CALM) program, Proceedings, Ninth International Conference on Permafrost, edited by: Hinkel, K. M. and Kane, D. L., University of Alaska Press, Fairbanks, Alaska, 1273-1280, 2008.

New, M., Liverman, D., Schroder, H., and Anderson, K.: Four degrees and beyond: the potential for a global temperature increase of four degrees and its implications, Phil. Trans. R. Soc. A, 369, 6-19, 2011.

NOAA (National Oceanic and Atmospheric Administration), Arctic Research Program: Arctic Report Card, edited by: Jeffries, M. O., Richter-Menge, J., and Overland, J. E., http://www.arctic. noaa.gov/reportcard, 2014.

Oksanen, J., Blanchet, F. G., Kindt, R., Legendre, P., O’Hara, B., Simpson, G. L., Solymos, P., Stevens, M. H. M., and Wagner, H.: vegan: Community ecology package, $\mathrm{R}$ package version 2.2-1, 2015.

Olefeldt, D., Turetsky, M. R., Crill, P. M., and McGuire, A. D.: Environmental and physical controls on northern terrestrial 
methane emissions across permafrost zones, Glob. Change Biol., 19, 589-603, 2013.

Payette, S., Delwaide, A., Caccianiga, M., and Beauchemin, M.: Accelerated thawing of subarctic peatland permafrost over the last 50 years, Geophys. Res. Lett., 31, L18208, doi:10.1029/2004GL020358, 2004.

Perreault, N.: Impact de la formation de ravins de thermo-erosion sur les milieux humides, Ile Bylot, Nunavut, Canada, MSc thesis, Université du Québec à Trois-Rivières, 104 pp., 2012.

Pouliot, R., Rochefort, L., and Gauthier, G.: Moss carpets constrain the fertilizing effects of herbivores on graminoid plants in arctic polygon fens, Botany, 87, 1209-1222, 2009.

$\mathrm{R}$ Development Core Team: R: a language and environment for statistical computing. R Foundation for Statistical Computing, Vienna, Austria, ISBN 3-900051-07-0, http://www.R-project.org, 2015.

Romanovsky, V. E., Smith, S. L., and Christiansen, H. H.: Permafrost thermal state in the polar Northern Hemisphere during the international polar year 2007-2009: a synthesis, Permafrost Periglac., 21, 106-116, 2010.

Rowland, J. C., Jones, C. E., Altmann, G., Bryan, B., Crosby, B. T., Geernaert, G. L., Hinzman, L. D., Kane, D. L., Lawrence, D. M., Mancino, A., Marsh, P., McNamara, J. P., Romanosky, V. E., Toniolo, H., Travis, B. J., Trochim, E., and Wilson C. J.: Arctic landscapes in transition: responses to thawing permafrost, Eos Trans. Am. Geophys. Union, 91, 229-236, 2010.

Sandvik, S. M. and Odland, A.: Changes in alpine snowbed-wetland vegetation over three decades in norther Norway, Nordic J. Bot., 32, 377-384, 2014.

Sarrazin, D. and Allard, M.: The thermo-mechanical behavior of frost-cracks over ice wedges: new data from extensometer measurements, 68th Canadian Geotechnical Conference and 7th Canadian Permafrost Conference, Quebec City, Canada, 7 pp., 2015.

Sedinger, J. S., White, R. G., Mann, F. E., Burris, F. A., and Kedrowski, R. A.: Apparent metabolizability of alfalfa components by yearling Pacific Black Brant, J. Wildl. Manage., 53, 726-734, 1989.

Seppälä, M.: Piping causing thermokarst in permafrost, Ungava Peninsula, Quebec, Canada, Geomorphology, 20, 313-319, 1997.

Sheard, J. W. and Geale, D. W.: Vegetation studies at Polar Bear Bass, Bathurst Island, N.W.T., I. Classification of plant communities, Can. J. Bot., 61, 1618-1636, 1983.

Shiklomanov, N. I., Streletskiy, D. A., Nelson, F. E., Hollister, R. D., Romanovsky, V. E., Tweedie, C. E., Bockheim, J. G., and Brown, J.: Decadal variations of active-layer thickness in moisturecontrolled landscapes, Barrow, Alaska, J. Geophys. Res., 115, G00I04, doi:10.1029/2009JG001248, 2010.

Shiklomanov, N. I., Streletskiy, D. A., Little, J. D., and Nelson, F. E.: Isotropic thaw subsidence in undisturbed permafrost landscapes, Geophys. Res. Lett., 40, 1-6, 2013.

Sjöberg, Y.: Linking water and permafrost dynamics, $\mathrm{PhD}$ thesis, Stockholm University, 27 pp., 2015.

Sjögersten, S., van der Wal, R., and Woodin, S. J.: Habitat type determines herbivory controls over $\mathrm{CO}_{2}$ fluxes in a warmer Arctic, Ecology, 89, 2103-2116, 2008.

Smith, S.: Trends in permafrost conditions and ecology in northern Canada: Ecosystem Status and Trends 2010, Technical Thematic
Report No. 9, Canadian Councils of Resource Ministers, Ottawa, ON, 22 pp., 2011.

Smith, S. L., Burgess, M. M., Riseborough, D., and Nixon, F. M.: Recent trends from Canadian Permafrost Thermal Monitoring network sites, Permafrost Periglac., 16, 19-30, 2005.

Smith, S. L., Wolfe, S. A., Riseborough, D. W., and Nixon, F. M.: Active-layer characteristics and summer climatic indices, Mackenzie Valley, Northwest Territories, Canada, Permafrost Periglac., 20, 201-220, 2009.

Svoboda, J. and Henry, G. H. R.: Succession in marginal arctic environments, Arct. Alp. Res., 19, 373-384, 1987

Tarnocai, C., Nixon, F. M., and Kutny, L.: Circumpolar-ActiveLayer-Monitoring (CALM) sites in the Mackenzie Valley, Northwestern Canada, Permafrost Periglac., 15, 141-153, 2004.

Treat, C. C., Natali, S. M., Ernakovitch, J., Iversen, C. M., Lupascu, M., McGuire, A. D., Norby, R. J., Chowdhury, T. R., Richter, A., Santruckova, H., Schädel, C., Schuur, E. A. G., Sloan, V. L., Turetsky, M. R., and Waldrop, M.: A pan-Arctic synthesis of $\mathrm{CH}_{4}$ and $\mathrm{CO}_{2}$ production from anoxic soil incubations, Glob. Change. Biol., 21, 2787-2803, 2015

Tveit, A. T., Urich, T., Frenzel, P., and Svenning, M. M.: Metabolic and trophic interactions modulate methane production by Arctic peat microbiota in response to warming, Proc. Natl. Ac. Sci., 112, E2507-E2516, doi:10.1073/pnas.1420797112, 2015.

USGCRP: Global Climate Change Impacts in the United States, edited by: Karl, T. R., Melillo, J. M., and Peterson, T. C., United States Global Change Research Program, Cambridge University Press, New York, NY, 2009.

ter Braak, C. J. F.: Canonical correspondence analysis: a new eigenvector technique for multivariate direct gradient analysis, Ecology, 67, 1167-1179, 1986.

Veillette, A., Fortier, D., and Godin, E.: Contrasting patterns of thermo-erosion gullies formed in syngenetic ice wedge polygonal terrains on Bylot Island, eastern Canadian Arctic: case studies from three different sedimentary environments, 68th Canadian Geotechnical Conference and 7th Canadian Permafrost Conference, Quebec City, Canada, 8 pp., 2015.

Vonk, J. E., Mann, P. J., Dowdy, K. L., Davydova, A., Davydov, S. P., Zimov, N., Spencer, R. G. M., Bulygina, E. B., Eglinton, T. I., and Holmes, R. M.: Dissolved organic carbon loss from Yedonna permafrost amplified by ice wedge thaw, Environ. Res. Lett., 8, 3, doi:10.1088/1748-9326/8/3/035023, 2013.

Woo, M.-K.: Permafrost hydrology, Springer, New York, NY, 564 pp., 2012.

Woo, M.-K. and Young, K. L.: High Arctic wetlands: their occurrence, hydrological characteristics and sustainability, J. Hydrol., 320, 432-450, 2006.

Woo, M.-K., Mollinga, M., and Smith, S. L.: Climate warming and active layer thaw in the boreal and tundra environments of the Mackenzie Valley, Can. J. Earth Sci., 44, 733-743, 2007.

Woo, M.-K., Kane, D. L., Carey, S. K., and Yang, D.: Progress in permafrost hydrology in the new millennium, Permafrost Periglac., 19, 237-254, 2008.

Wright, N., Hayashi, M., and Quinton, W. L.: Spatial and temporal variations in active layer thickness and their implication on runoff generation in peat-covered permafrost terrain, Water Resources Res., 45, W05414, doi:10.1029/2008WR006880, 2009.

Zamin, T. Z., Brett-Harte, M. S., and Grogan, P.: Evergreen shrubs dominate responses to experimental summer warming and fer- 
tilization in Canadian mesic low arctic tundra, J. Ecol., 3, doi:10.1111/1365-2745.12237, 2014.

Zoltai, S. C., McCormick K. J., and Scotter, G. W.: A natural resource survey of Bylot Island and adjacent Baffin Island, Northwest Territories, Parks Canada, Ottawa, ON, 176 pp., 1983.
Zuur, A. F., Ieno, E. N., and Smith, G. M.: Analysing ecological data, edited by: Gail, M., Krickeberg, K., Samet, J., Tsiatis, A., and Wong, W., Springer, New York, 672 pp., 2007. 